\title{
Policing organized crime
}

\section{A new direction}

\author{
Frederik E. Jansen and Gerben J.N. Bruinsma ${ }^{1}$
}

Until a few decades ago, the police were mainly a reactive bureaucratic organization that moved from one criminal event to the next, according to the degree to which the outside world required its services. Since then the police have abandoned the emphasis on law enforcement with regards to petty crime and public order. More recently the police have developed community policing as an important strategy in which preventive and pro-active operations are considered to be more useful and effective than exclusively enforcing criminal law after the offence has been committed (see Aronowitz, in this issue). However, in their approach to organized crime and various types of organizational crime, the police continue to operate in the same way as they have done for years. Based on victims' reports or criminal intelligence, the police will conduct surveillance on a criminal group, establish a special police team within the department specialized in the crime concerned and will try to arrest the members (and preferably the leaders of the group), and ensure that enough evidence is available to result in a prosecution. This process requires thorough and time-consuming detective work.

Until recently the police viewed organized crime as Mafia-like families with strict discipline and a hierarchical structure, in which one or two leaders carry out specialized tasks using violence, as if it were a company or a governmental organization. To a certain degree that Godfather Myth is still alive in the police force. In short, police (and public prosecutors) considered organized crime to

1 Respectively Commissioner of Police and head of the Division Organized Crime of the Twente Police force and Professor of criminology and director of the International Police Institute (IPIT) at the University of Twente. PO Box 217,7500 EA Enschede. The Netherlands. We would like to thank Alexis Aronowitz of the IPIT for her comments on an earlier draft of this paper and for her grammatical corrections, as well as the members of the editorial committee for their suggestions for improvements. 
be a phenomenon that was isolated from society, to which they could only respond through enforcement of the criminal law. However, there is no empirical research supporting the effectiveness of this crime fighting approach. Furthermore, over the years, some police forces have come to realize that this approach has proven to be unsuccessful. Indeed, a number of criminal groups have been disbanded and their members convicted every year. but the truth of the matter is that in most cases better organized groups have quickly replaced those which have been disbanded, and the process of criminal investigation must start all over again.

Some police forces in the Netherlands have sought new strategies to handle organized crime. They realize that innovations have mainly affected (information) technology and criminal investigation methods. External influences in this area of policing were rare. A possible explanation is that is was only the police' who really understood organized crime, and information on the subject was kept a closely guarded secret, to which others were not privy. Outsiders were automatically excluded from these police sources (Marx, 1984). It became almost impossible for criminologists to conduct independent scientific research, which led to a lack of systematic empirical knowledge of this significant social phenomenon. This resulted in a lack of understanding of organized crime, the types of criminal groups, their methods and the social context in which these groups operate and develop their illegal activities. Most research studies written by criminologists on the subject have been fragmented and incomplete. However, in order to develop new pro-active and preventive strategies the police need reliable access, authorative knowledge and an overall picture of organized crime, which will enable them to gain some insight in the societal context in which organized crime is embedded, the causes of its origins and growth. Until recently the police in our country have lacked this systematic insight.

\section{Organized crime in the Netherlands}

At the beginning of 1995 the Dutch Parliament initiated a Parliamentary Committee to inquire into undercover police methods. In order to assess the police methods used, the Committee was of the opinion that a scientific description of the organized crime situation in the Netherlands was necessary. The problem faced by the Parliamentary Committee was that the picture of the situation the police had presented over the previous years was biased and incomplete. This biased and incomplete picture was a consequence of the relative autonomy of the police forces and the fragmented, non-systematic and poorly structured way in which information was gathered.

In order to get a reliable and valid view on the problem of organized crime, 
the Parliamentary Committee invited four independent professors in criminology from four different universities, who came to be known as the Fijnaut group (Fijnaut, Bovenkerk, Bruinsma and Van de Bunt), to conduct a descriptive study on the nature and the extent of organized crime in the Netherlands (Fijnaut et al., 1996). The group of criminologists was also asked to develop a definition of organized crime and a method to conduct empirical research in this area.

In the criminological literature there was no example of research designs for such a large-scale empirical study as they had to conduct. There were, of course, criminological studies in the field of organized crime, but these were small-scale research projects which were unsuitable for an empirical study for a whole country.

For their study, the police forces submitted the empirical data in the form of all existing police files (more than 600 reports and all kinds of confidential information on persons, criminal groups and networks), as well as files from all other special police forces. The researchers also held interviews (approximately 400 ) with members from local and ethnic minority communities, experts and others in various legal sectors, labour unions, and so on. All the information was evaluated in the light of criminological and sociological knowledge of society, because crime in general and organized crime cannot be described or understood outside the societal context.

Organized crime has been an issue of debate among criminologists for years. In the Netherlands criminologists and practitioners have faced the same problem: that of achieving a single, 'workable' and operational definition of organized crime. Some define organized crime as a form of crime which is organized as a regular family-based business organization which closely resembles the Italian Mafia as depicted in the movie The Godfather. Others are of the opinion that every group activity in crime in which some form of cooperation is involved, is organized crime. Both views have been challenged by this empirical study.

The Fijnaut group defined organized crime as 'a group or network of people which is primarily focused on illegally obtained profits, and in a systematic way commit serious crimes with great societal consequences. These groups or networks are capable of effectively covering up their crimes, in particular by using violence or means of corruption' (Fijnaut et al., 1996, pp. 24-25). From an analytical point of view they distinguished organized crime from professional crime, corporate crime, terrorism and white-collar crime. Based on this definition organized crime currently comprises two essential kinds of criminal activities: on the one hand the supply of illicit goods and services and on the other hand the infiltration of legitimate business (construction industry, harbours, toxic waste industry, transportation, banking). The illegal markets in 
the Netherlands are mainly concerned with the trading and selling of drugs: heroin; cocaine; marijuana and hashish, XTC; and of other illegal goods and illegal services: ranging from arms smuggling, stolen cars, to illegal immigrants from all over the world (especially prostitutes). Further illegal activities include the production and trade in pornography, illegal gambling, loan sharking, money laundering; and international frauds, including EU-fraud.

No systematic criminal infiltration of or racketeering in any particular sector in the Netherlands was found in the available data. Control by criminals of the ports, construction industry, trade unions, as in (parts of) the USA, Japan or Italy is not empirically demonstrated here. However, on a small scale, some segments of the Dutch society have been infiltrated by criminal groups. In certain areas in larger cities the catering and restaurant industry is slowly coming under their control, and a small number of trucking companies have been taken over by criminal groups to facilitate their drug smuggling activities. Furthermore, a small but significant number of dishonest lawyers has been corrupted by criminal groups. These lawyers are helping criminal groups to cover up crimes and to transfer 'criminal' money into the legal economy in the Netherlands or elsewhere in the world.

There is no such thing as the organized crime in the Netherlands. The empirical research indicates that there is a differential picture of organized crime in the Netherlands. The groups vary from loosely structured networks to tightly organized, solid families operating within the Dutch societal context. In addition to Dutch criminal networks, ethnic and international criminal groups are operating here: Surinam criminal groups, Turkish and Moroccan families. Russian criminal groups, Yugoslavian gangs, Chinese triads, Italian Mafia families, and Nigerian and Ghanese networks. By using or implicating their own personal friends and acquaintances, organized crime groups are involving several ethnic communities in our cities. In particular, the Turkish, Moroccan and Surinam communities in the Netherlands are partially dependant on the drugs economy. Geographically there is a great variation in groups and activities. The smuggling and distribution of drugs are the main illegal activities of the majority of the criminal groups. There is a fine-meshed distribution structure all over the Netherlands for the supply of heroin, cocaine, hash, marijuana and synthetic drugs. Even in very small villages, drugs can be bought from petty dealers or in so-called coffee shops. Most of the drug trafficking activities involve drugs in transit to other countries in Europe or to the United States. The Netherlands is functioning as a market-place, one of the many market places in the world.

Within the allotted time frame, the four researchers not only endeavoured to obtain a picture of the situation on a national scale, but also conducted four local studies that were to enhance national policy in this respect. One of these 
studies, in the city of Enschede (the largest city in the Twente region; 147,000 inhabitants), the picture of organized crime is also essentially determined by drug trafficking (Bruinsma and Van de Bunt, 1996). The quantity and the quality of the organized crime groups, however, differ from those operating in the western part of the Netherlands (especially Amsterdam). Criminal groups (especially Turkish) focus on heroin and cocaine trafficking, but do not dominate the trade. The criminal market is relatively open, which means that newcomers are not excluded and that there is no struggle for hegemony in the drugs market. There are very few physical confrontations between groups. The criminal groups are relatively loosely structured and are organized around a few main figures who have built a personal network around themselves. If necessary, others are involved to do odd jobs. The personal networks are predominantly based on family and ethnic relations. As a consequence of the open structure of the drugs market, a relatively large part of the ethnic communities is somehow involved in hard drug trafficking. Migrants are also involved in the trafficking of women and local prostitution.

\section{Some policy implications}

The empirical research on organized crime in our country makes clear that organized crime is the result of a complex process (especially in the field of drug trafficking). Reuter's (1986, p. 174) statement that 'criminals do not inhabit a social and physical world that is different from the rest of society. They walk the same streets, dine in the same restaurants, and send their children to the same schools' was confirmed by the Fijnaut group. The findings have policy implications for the police and the government on a national and a local level. To mention a few:

- there is no systematic infiltration of or racketeering in legal sectors;

- there is hardly any corruption of policemen, public prosecutors, judges, mayors, civil servants or representatives of industries and of labour unions (only in incidental cases were there some indications of corruption);

- organized crime groups operate internationally (with the aid of new communication technologies) in buying and selling illegal goods like drugs, but they have their bases in the local community where they are dwelling;

- because of a lack of interest and because of the way police forces are organized, local criminals have every opportunity to grow into organized crime groups;

- once an organized crime group has settled in an area or neighbourhood, it is very difficult, if not impossible to get them out of it;

- organized crime groups act as a role model for youngsters in a marginal economic and social position; 
- organized crime groups make use of the social and economic (infra)structure of the city to deal in all kinds of drugs and to launder their criminal money by buying on a small scale real estate or bars, cafeterias and restaurants in the centre of the cities and by the exploitation of so-called 'coffee shops'; they also make use of shops, (import and export) firms, and all kinds of private companies to cover up their illegal activities:

- the local market for hard drugs is small because of the relatively low number of drug addicts in the region; however the local market for soft drugs (marijuana, hashish) is larger because of the greater number of local users of all ages, but especially youngsters;

- ethnic organized crime groups make use of the marginal position of the local ethnic communities by paying people to become involved in all kinds of minor illegal activities of these groups.

\section{The underlying assumptions of policing organized crime}

The newly acquired empirical knowledge of organized crime at the national and local level presented new opportunities to develop unique strategies for policing. The study showed that organized crime is a complex social phenomenon that develops within a dynamic social context, manifests itself in different ways and that has embedded itself in society through symbiotic relations. Therefore, it cannot solely be combated by means of measures stemming from criminal law. Criminal law is, as an ultimum remedium, the last link in a chain of possibilities, which can be used to fight organized crime. Fighting organized crime can only be effective if other instruments are brought into play, and this requires an understanding and knowledge of the development and operation of organized crime within a society, and also knowing possible ways to counteract it, or even knowing how to prevent criminal groups from carrying out their illegal activities.

Until recently, the police were used to conducting surveillance on criminal organizations by setting up special teams. These teams were then instructed to ultimately produce an official report that provided sufficient criminal evidence to convince the judge that it was indeed a criminal organization. This repression by head hunting is, of course, useful but hardly be classed as effective police work. Up till now 'there is no evidence that these successful prosecutions have in any way negatively impacted or altered the activities of organized entrepreneurial groups in illicit markets' (Potter, 1994, p. 182).

Potter demonstrates that organized crime adapts a contigency strategy to its environment as a response to more repression. 'The reason that no impact on organized crime can be demonstrated as a result of the head hunting approach is that the model underlying that approach is wrong. Organized crime groups 
learned long ago that to be successful in a threatening legal environment they must be prepared to adapt their structures and practices. The irony of the situation is that the more successful federal prosecutors become in incarcerating organized crime leaders, the more the industry responds by decentralizing and maintaining temporary and ephemeral working relationships. Because the head hunting approach never disables more than a small proportion of the total number of organized crime entrepreneurs at a given time, it actually strengthens and rewards some organized crime groups by weeding out their inefficient competitors' (Potter, 1994, p. 180).

However, a great number of the authors in the field of organized crime (e.g. Goldstock, 1991; Dombrink and Huey-Long Song, 1994) acclaims the intensification of the repressive approach: more and better co-operation between investigation agencies, a war against corruption, more infiltration, more wiretapping, electronic surveillance, witness protection, more pro-active techniques in the investigations.

However, all these strategies are based on the organized crime situation in (parts of) the United States or countries like Italy, Colombia or Japan. In the Netherlands, especially the eastern part of the Netherlands, the situation is as demonstrated before, less serious: there is hardly any infiltration in the legal sectors of society, there is very little evidence of corruption in the police and in local and national government and private organizations are not yet infected by organized crime. This situation has provided the opportunity to develop new strategies in fighting organized crime, in which the police play an important role, but: 'it cannot do the whole job by itself. It is essential that other sectors, especially other agencies of government, become strongly involved in the hard work of social control. They cannot be allowed to turn a blind eye toward organized crime racketeering or to dismiss organized crime as 'a law enforcement problem" (Jacobs, 1991, p. 132). With this knowledge in mind, the question arises whether or not to implement the strategy of community policing in the field of organized crime. Community policing in the main city of Enschede was more or less effective in controlling traditional crimes like robberies, burglaries, violence and petty drug dealing (Kroes and Scholtens, 1996).

\section{Policing organized crime in Twente}

The uncertainty of the effectiveness of this approach was a sufficient reason for the Twente regional police force. This region is situated close to the German border in the eastern part of the Netherlands and occupies $1,437 \mathrm{~km} 2$. In the region live 587,987 inhabitants in three big cities (Enschede, Hengelo and Almelo) and the surrounding rural area. The police force has about 1,430 
employees, policemen and policewomen, as well as civilians. The police force is organized in four districts with 21 local police-departments. In those local departments community policing is has been practised for some time. In a special organized crime branch of the police more than 140 detectives, analysts and civilians are active in developing a 'supplementary' working method. This new method is supplementary because the usual repressive procedure continues to be necessary. The supplementary strategy was to be of a preventive or pro-active nature. In order to fight organized crime, a proactive approach necessitates co-operation with external partners. The police have knowledge and experience regarding organized crime, but potential partners (such as public authorities, the department of Public Prosecution, trade unions, local communities, legal sectors, industrial organizations or management of large companies) have the power to take the necessary preventive or obstructive measures. By ensuring that every partner cooperates, utilizing its own area of expertise, barriers can be built against organized crime. To that effect, these partners must be informed about the possible threats from criminal groups.

A novelty in the approach of the Twente police is that it focuses on two mutually complementary strategies: traditional investigation, based on criminal law, of illegal activities of criminal groups in which modern methods are used; and developing measures. together with public and private partners. to hinder criminal groups in their efforts to expand their illegal activities and thus from presenting a threat to democratic and economic liberties in this (part of the) country. Implementing such measures implies that knowledge or expertise of the partners be compiled and shared. The police, obviously, have the necessary know-how, but have been using it ineffectively and have prevented others from benefiting from it.

\section{The organization of the criminal investigation process}

The Twente police force has decided to take a more organized and structured approach to fighting organized crime, and has determined that police work shall not be led so much by unexpected events, when the seriousness of the offence and the required police effort cannot be predicted. A five-step model has been developed to that effect, in which particular partners and police officers play a specific role. This model consists of the following stages (see Figure 1). 


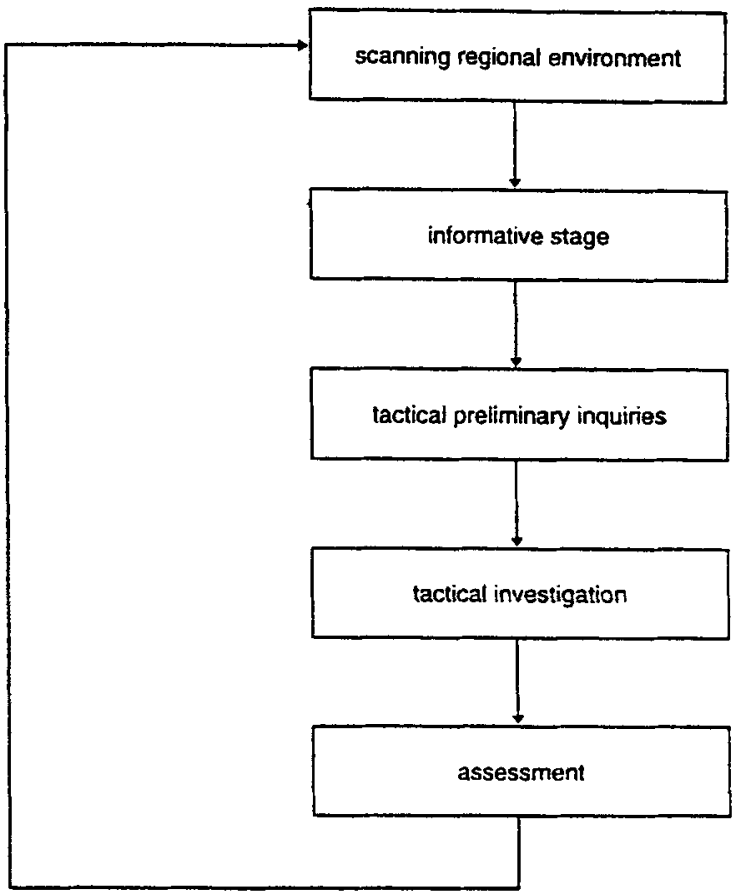

\section{Scanning the regional environment}

The stage involving scanning the environment is intended to establish a complete picture of crime in the Twente region. It points out which factors in the region increase the potential for organized crime, such as the geographic location near the border or the demographic and economic situation and the infrastructure of private businesses and public authorities. This picture is used to inform the authorities and the relevant partners of the police and to identify potentially worrisome situations and to determine which businesses or organizations are being threatened by criminal groups. It also identifies what priorities in the integral approach are to be set and what factors the participants in community policing can influence to prevent organized crime growing in their regional environment. This scan of organized crime is undertaken in co-operation with the International Police Institute Twente of the University of Twente (co-ordinated by the co-author of this article). To that effect, police sources, criminological knowledge and all kinds of other information from society are integrated. In due course, the police force itself will carry out the reconnaissance periodically in order to have an actual picture of the crime situation in the area. 


\section{Informative stage}

Once the priorities are set by the authorities, the informative stage focuses on a number of selected neighbourhoods, businesses or organizations and the potential for and signs of organized crime in these neighbourhoods and businesses. This more specific picture is used to provide partners with information and advice concerning prevention. It also serves to determine which preliminary criminal inquiries are to be started against possible criminal organizations. In this stage the police and the public prosecutor will inform the relevant partners about the general factors conducive to organized crime. For the public office, for instance, it is relevant to know what activities and what parts of its organization are sensitive to corruption or infiltration by criminal groups. The catering and restaurant industry must be informed about protection rackets by criminal groups and the risks of being susceptible to financial offers by unknown financiers.

\section{Tactical preliminary inquiries}

In the tactical preliminary inquiry stage the detectives of the Organized Crime Division focus on the activities of a specific group of criminal offenders. The knowledge generated in this stage is used in the subsequent stage to establish the goals and tactics of the inquiry. It also serves to determine, more specifically, which measures can be taken to prevent certain types of crime committed by particular criminal groups. In this stage relevant information from the tactical investigation stage of the police is shared with specific organizations or companies. The sharing of sensitive criminal information with relevant partners is one of the fundamental problems in an integral approach, and it is for this reason that the legislator has not yet regulated this kind of information transfer. In more factual police advice there are, of course, many pitfalls. Which information can the police share with others? Only offences proven by the judge or also confidential criminal intelligence? The Act on police registers' and the Netherlands' privacy legislation introduce many limitations in this respect. Information that is not related to individuals or companies is easier to transfer.

\section{Tactical investigation}

The stage of the tactical investigation (the project) focuses on the criminal investigation of a criminal organization, including seizing the capital acquired. This stage concentrates on the modus operandi of the criminal group and should lead to the arrest of suspects. Furthermore, it also provides a wealth of information regarding what measures can be taken in the future and serves to inform the partners as to how criminal groups operate and what options are available for counteracting their operations. 
Due to the nature of their work, the police have considerable knowledge unrelated to criminal law, know- how that could be used more efficiently. This knowledge is acquired by gathering substantial information on the activities and people targeted in investigations. Imagine that a Chinese person were to be found dead. A team of detectives would start working on the case. Through interrogations and investigations into the victim's background, his lifestyle, working habits, communications, method of doing business and his personal relations within his own circle of Chinese acquaintances, the team will acquire a great deal of factual information. Much of this information is obtained from understanding Chinese customs and traditions (with all the regional differences), the manner of formal and informal communication and the activities that take place within the closed Chinese community as well as those who become their victims, etc. If the criminal investigation is successful, the information will ultimately result in the case being solved, and possibly in the conviction of the suspect(s). Following disbandment of the team of detectives, the organization at large, but not the individual detectives, will lose the information that does not directly serve as criminal evidence. Abundant knowledge and opportunities are thus lost, resulting in the inability to solve a similar criminal case in the future. But more importantly, the knowledge could contribute towards future preventive measures.

\section{Assessment}

The assessment stage generates information on the development of the criminal procedure, the results and the role the various partners have played in the process. The assessment stage is indispensable if the approach is to be continually improved (Geerdink, 1997). Together with the public and private partners the police evaluate the contribution each have made during the previous period and what has to be improved in the future.

The five-stage model described above also represents a process of sharing information. Both police and other organizations gather external and internal information. The extent of the role of the police will depend on the stage the process is in. This entire process of gathering, processing and supplying information is not only of strategic importance to the police, but just as. valuable for their partners.

Preventive and pro-active work thus require a great deal of co-operation with external partners. The police act as consultants, explaining which measures the partners should take. On the other hand, these partners will have accumulated information and experience through their own line of work which could benefit the Division Organized Crime. Four kinds of activities were developed in order to implement the new strategy: 
- the police give advice to and co-operate with the partners, together developing and implementing policy instruments in the region;

- the entire police force is involved in improving the gathering of information resulting in less dependence on the small Criminal Intelligence department community policing is therefore implemented quite consciously in fighting organized crime;

- the organization has been equipped with an information desk that provides all police officers with relevant information 24 hours a day (even sensitive/ confidential information);

- the criminal investigation into organized crime will be less reactive, and more of an organized and structured management plan based on reliable and valid knowledge of the police's social environment: the regional picture of organized crime.

\section{Preliminary findings}

The implementation of the new policing strategy started in the middle of 1996 . a few months after the Fijnaut group reported its criminological research on the extent and nature of organized crime in the Netherlands. This short period precludes any far-reaching conclusions about the effectiveness of this method of policing organized crime in the Twente area. However, some preliminary findings can be reported.

Since the middle of 1996, some Division staff members have been given the task of keeping in touch with and advising external partners. These officials are expected to influence the environment through mobilizing partners with regard to reducing the opportunities for organized crime activities. They inform public authorities on corruption and together with public authorities, they analyze areas where public officials are prone to corruption (e.g. granting licences). Other police officers of the Division have, together with industrial organizations, been describing and analysing areas in specific sectors, such as the hotel and restaurant industry or the construction industry, that could be sensitive to infiltration. For example, how susceptible is the regional hotel and restaurant industry or the real estate industry to acting as a cover-up for criminal groups that are dealing in drugs? The same policemen provide information, based on experience, on signs of illegal activities in a specific line of business. For instance, they inform partners on how to recognize a suspicious offer concerning investment in real estate. Furthermore, a so-called regional platform was set up in which several partners work together in studying and discussing integral policy instruments, addressing problems surrounding organized crime groups.

In addition to the business-related contacts which facilitate a better under- 
standing of potential low thresholds for the development of crime, it is extremely important that use be made of the organization's potential sources of information. One of the outcomes of the criminological study of the Fijnaut group is that while members of criminal groups do indeed operate internationally, they continue to live in their own neighbourhood, near their relatives and friends. They also develop criminal activities in the environment in which they live. Police officers work in these neighbourhoods every day and besides criminal offences, also notice other things that could be relevant to broadening our understanding of organized crime. The fact that, despite few customers, small businesses grow very quickly, or that visitors keep coming and going from certain buildings, must attract attention. Moreover, police officers will obtain information from the people who live in those neighbourhoods and from the public at large regarding the dealings in these businesses (hotel and restaurant business, tailor shops, building companies). The police constables are therefore taught to look at their work not only from a reactive, criminal law related point of view, but to start taking a pro-active approach.

A satisfactory organization of police information is an important prerequisite for actually converting know-how into results to enhance safety and the quality of life in society, and to address and reduce the most serious of crimes in a broad sense. That is why the Twente police force has established an information desk that assists all police officers in Twente (approximately 2400 'eyes and ears') 24 hours a day. All operational information, even sensitive 'criminal intelligence' is available. The 'desk research' carried out 24 hours a day, enables the police to establish links with information required or gathered in the neighbourhoods. The staff of the information desk has all the information at hand, as well as information on organized crime. In this manner, we endeavour to benefit more from knowledge and information present in basic police work.

\section{Conclusions}

Recent criminological research in the Netherlands underscores the fact that organized crime is embedded in society and the overall picture makes it clear that police emphasis on a crime fighting model of the police, based solety on criminal law will not be entirely effective. Therefore, the Twente police force developed a new strategy of policing organized crime in their region. This strategy is based on criminological knowledge and on the approach of community policing: preventive, pro-active and integrated actions taken by various partners of the police in order to reduce illegal activities of organized crime groups. This strategy, however, can only succeed when two conditions are satisfied. First, this approach can only function in an open democratic society 
in which numerous public and private organizations and the public feel responsible for the emergence of organized crime in their environment. Secondly, the police force and their partners must be (relatively) free of corruption. This implies that this strategy can only be effective in societies in which organized crime has not deeply penetrated democratic institutions and business organizations.

\section{References}

Bruinsma, G.J.N., H.G. van de Bunt De georganiseerde criminaliteit in Nederland; een analyse van de lokale situatie in Enschede, Nijmegen en Arnhem

The Hague, Sdu, 1996

Divisie Georganiseerde Criminaliteit Elimineren en adviseren

Enschede, Politie Twente, 1996

Dombrink, J., J. Huey-Long Song

Policing emerging organized crimegroups. In: R.J. Kelly et al. (eds.), Handbook oforganized crime in the United States

Westport. Greenwood. 1994, pp. 415-430

Fijnaut, C., J. Jacobs (eds.)

Organized Crime and its Containment; $A$ Transatlantic Initiative

Deventer/Boston, Kluwer, 1991

Fijnaut, C., F. Bovenkerk et al.

De georganiseerde criminaliteit in

Nederland: eindrapport

The Hague, Sdu, 1996 (this study will be published in English in the beginning of 1998 by Kluwer International)

\section{Geerdink, H.F.X.}

Aangepakt \& uitgepakt (doctoral thesis)

Enschede, IPIT-scriptie, 1997

Goldstock, R.

Organized crime and anti-organized crime efforts in the United States: an overview. In: C. Fijnaut, J. Jacobs (eds.), Organized Crime and its Containment; $A$ Transatlantic Initiative

Deventer/Boston. Kluwer, 1991, pp. 7-14 Jacobs, $J$.

The failures of American law enforcement in combating organized crime. In: C. Fijnaut, 1. Jacobs (eds.), Organized Crime and its Containment; $A$ Transatlantic Initiative

Deventer/Boston, Kluwer, 1991, pp. 121. 134

Kroes, L., H.N. Scholtens

Politie en de zorg voor veiligheid

Enschede, IPIT, 1996

\section{Marx, G.T.}

Notes on the discovery, collection, and assessment of hidden and dirty data. In: J.W. Schneider, J.J. Kitsuse (eds.).

Studies in the Sociology of Social

Problems

Ablex, Norwood, 1984, pp. 78-113

Potter, G.W.

Criminal Organizations; Vice, Racketeering and Politics in an American City

Prospects Heights, Waveland Press, 1994

Reuter, P.

Disorganized Crime; Illegal Markets and the Mafia

Cambridge, MIT-Press, 1986 